\title{
PENGARUH BAWANG MERAH TERHADAP PENURUNAN KADAR GULA DARAH PADA PENDERITA DIABETES MELLITUS DI DESA SIDORAHARJO KECAMATAN KEDAMEAN KABUPATEN GRESIK
}

\author{
Siti Aminah Hidayat, Chilyatiz Zahroh \\ Fakultas Keperawatan dan Kebidanan \\ Universitas Nahdlatul Ulama Surabaya, Jln. SMEA 57 Surabaya \\ Email: chilyatiz@unusa.ac.id
}

\begin{abstract}
People living in Desa Sidoraharjo were more familiar with oral medication to control glucose level ini the blood, namely oral anti-diabetic drugs (OADs) than herbal medicine onion. The purpose of this study was to know the effect of onion toward decrease blood glucose levels in people with Diabetes Mellitus. The study using preexperimental one group pretest-posttest involved population taken from all people found with Diabetes Mellitus, totaling 15 patients. The samples chosen using simple random sampling technique were 14 patients in total. The independent variable was onions, whereas the dependent variable was blood glucose level. The instrument used in this study was autocheck self-monitoring of capillary blood glucose. Moreover, the data were analyzed using Wilcoxon signed-rank test with level of significance $\alpha=0,05$. The result of study showed that blood glucose level on average before consuming onions was $278,93 \mathrm{mg} / \mathrm{dL}$, whereas after onions treatment, the average blood glucose level decreased to $251,64 \mathrm{mg} / \mathrm{dL}$. The result of Wilcoxon signed-rank test showed that the level significance $\rho=(0,001<\alpha)$ so that the use of onions brought effects to the decrease of blood glucose level. The use of onions as herbal medication can decrease blood glucose level as another alternative intervention to control blood glucose level of the patients with Diabetes Mellitus. besides consuming onions, those patients are also expected to visit medical workers periodically to prevent hypoglycemia.
\end{abstract}

Keywords: Diabetes Mellitus, blood glucose level, onion

\begin{abstract}
Abstrak : Masyarakat Desa Sidoraharjo lebih mengenal pengobatan medis sebagai pengontrol kadar gula darah yaitu OAD (Oral Anti Diabetes) daripada pengobatan herbal bawang merah. Tujuan penelitian ini untuk mengetahui pengaruh bawang merah terhadap penurunan kadar gula darah pada penderita diabetes mellitus. Desain penelitian ini menggunakan rancangan pra-experiment one group pretest-posttest. Populasinya adalah semua penderita diabetes mellitus sebesar 15 penderita. Sampel diambil secara simple random sampling sebesar 14 penderita. Variabel independen adalah bawang merah dan variabel dependen adalah kadar gula darah. Instrumen yang digunakan adalah alat cek kadar gula darah kapiler Autocheck. Data dianalisis menggunakan Wilcoxon signed ranks test dengan tingkat kemaknaan $\alpha=0,05$. Hasil penelitian didapatkan rata-rata kadar gula darah sebelum dan sesudah diberikan bawang merah sebesar $278,93 \mathrm{mg} / \mathrm{dL}$ dan $251,64 \mathrm{mg} / \mathrm{dL}$. Hasil Wilcoxon signed ranks test didapatkan tingkat signifikan $\rho=(0,001<\alpha)$ berarti ada pengaruh bawang merah terhadap penurunan kadar gula darah. Bahan herbal bawang merah mampu menurunkan kadar gula darah sehingga dapat menjadi intervensi lain pengontrol kadar gula darah penderita diabetes mellitus. Penderita DM yang mengonsumsi bawang merah diharapkan tetap mengontrol kadar gula darah secara berkala ke petugas kesehatan agar tidak terjadi hipoglikemia.
\end{abstract}

Kata kunci : Diabetes mellitus, kadar gula darah, bawang merah 


\section{PENDAHULUAN}

Masyarakat Desa Sidoraharjo lebih mengenal pengobatan medis sebagai pengontrol kadar gula darah yaitu OAD (Oral Anti Diabetes) misalnya metformin. Metformin memiliki efek samping yang umum adalah kram perut, diare, kembung, dan obat ini tidak boleh digunakan oleh penderita yang memiliki masalah hati dan ginjal (Hasdianah, 2012). Penggunaan OAD dalam jangka panjang dapat menyebabkan gangguan absorpsi vitamin B12 dan asam folat di saluran cerna, penurunan fungsi tiroid, peningkatan hemosistein, sehingga memicu serangan jantung, stroke bahkan kematian. Oleh karena itu diperlukan alternatif lain yang lebih aman untuk mengontrol kadar gula darah penderita diabetes mellitus.

Angka kejadian diabetes mellitus di Puskesmas Slempit, pada tahun 2015 berdasar pada data awal adalah sebanyak 507 kasus. Sedangkan prevalensi di Desa Sidoraharjo menurut data terpadu Ponkesdes Sidoraharjo sebanyak $24 \%$ dari 5011 jiwa. Masyarakat Desa Sidoraharjo tidak biasa memeriksakan gula darah secara rutin ke penyedia layanan kesehatan yang ada karena lebih disibukkan dengan rutinitas sehari-hari.

Resistensi insulin penderita diabetes mellitus dapat disebabkan oleh beberapa faktor yaitu kelainan genetik, usia, gaya hidup stres, pola makan yang salah, obesitas, dan infeksi (Riyadi \& Sukarmin, 2008). Resistensi insulin mengakibatkan peningkatan kadar gula darah. Kadar gula darah tinggi dan berlangsung lama akan memicu terjadinya komplikasi dan gangguan metabolisme lain. Jika hal tersebut tidak segera ditangani maka semakin besar angka kematian penderita diabetes mellitus sehingga akan menimbulkan masalah kesehatan yang serius.

Penelitian ilmiah telah menegaskan efektivitas beberapa tumbuh-tumbuhan tertentu untuk mengatasi diabetes salah satunya adalah bawang merah. Dari hasil penelitian yang dilakukan oleh Tri Purwaningsih FMIPA Farmasi UI tahun 1991, ternyata ekstrak umbi bawang merah dengan dosis $250 \mathrm{mg} / \mathrm{kg} \mathrm{BB}$, menyebabkan penurunan kadar gula darah normal sebesar 23,46\% (Fadhli, 2013).

Berdasarkan uraian di atas, penulis tertarik untuk melakukan penelitian tentang pengaruh bawang merah terhadap penurunan kadar gula darah pada penderita diabetes mellitus di Desa Sidoraharjo, Kecamatan Kedamean, Kabupaten Gresik.

\section{METODE}

Desain penelitian ini menggunakan rancangan pra-experiment one group pretest-posttest. Populasinya adalah semua penderita diabetes mellitus sebesar 15 penderita. Sampel diambil secara simple random sampling sebesar 14 penderita. Variabel independen adalah bawang merah dan variabel dependen adalah kadar gula darah. Instrumen yang digunakan adalah alat cek kadar gula darah kapiler Autocheck dengan observasi setiap 2 hari sekali dalam 14 hari. Perlakuan responden dengan pemberian bawang merah $100 \mathrm{mg} / \mathrm{kgBB}$ yang dijadikan serbuk lalu dimasukkan ke dalam kapsul selama 14 hari setelah makan siang. Data dianalisis menggunakan Wilcoxon signed ranks test dengan tingkat kemaknaan $\alpha=0,05$.

\section{HASIL \& PEMBAHASAN a. Hasil}

Tabel 1 Hasil pemeriksaan kadar gula darah penderita (responden) diabetes mellitus di Desa Sidoraharjo, Kecamatan Kedamean, Kabupatem Gresik sebelum pemberian bawang merah 100 $\mathrm{mg} / \mathrm{kgBB}$ yang dijadikan serbuk selama 14 hari.

\begin{tabular}{|l|l|l|}
\hline $\begin{array}{l}\text { Kadar Gula } \\
\text { Darah Tertinggi }\end{array}$ & $\begin{array}{l}\text { Kadar Gula } \\
\text { Darah } \\
\text { Terendah }\end{array}$ & Mean \\
\hline 380 & 212 & 278,93 \\
\hline
\end{tabular}

Sumber: Data Primer April-Mei 2016 
Pada tabel 1 menunjukkan bahwa ratarata hasil pemeriksaan kadar gula darah 14 penderita (responden) diabetes mellitus di Desa Sidoraharjo, Kecamatan Kedamean, Kabupaten Gresik, sebelum pemberian bawang merah $100 \mathrm{mg} / \mathrm{kgBB}$ yang dijadikan serbuk adalah 278,93 mg/dL.

Tabel 2 Hasil pemeriksaan kadar gula darah sewaktu penderita (responden) diabetes mellitus di Desa Sidoraharjo, Kecamatan Kedamean, Kabupatem Gresik sesudah pemberian serbuk bawang merah $100 \mathrm{mg} / \mathrm{kgBB}$ selama 14 hari.

\begin{tabular}{|l|l|l|}
\hline $\begin{array}{l}\text { Kadar Gula } \\
\text { Darah } \\
\text { Tertinggi }\end{array}$ & $\begin{array}{l}\text { Kadar Gula } \\
\text { Darah } \\
\text { Terendah }\end{array}$ & Mean \\
\hline 361 & 189 & 251,64 \\
\hline
\end{tabular}

Sumber: Data Primer April-Mei 2016

Pada tabel 5.11 menunjukkan bahwa rata-rata hasil pemeriksaan kadar gula darah 14 penderita (responden) diabetes mellitus di Desa Sidoraharjo, Kecamatan Kedamean, Kabupaten Gresik, setelah pemberian serbuk bawang merah $100 \mathrm{mg} / \mathrm{kgBB}$ adalah $251,64 \mathrm{mg} / \mathrm{dL}$ dengan rata-rata selisih 27,29 $\mathrm{mg} / \mathrm{dL}$. Terlihat variasi penuruan kadar gula darah pada hari ke 2 , hari ke 4 , hari ke 6 , hari ke 8 , hari ke 10 , hari ke 12 , dan hari ke 14, hal ini dikarenakan perbedaan respon yang dihasilkan dari masing-masing responden terhadap serbuk bawang merah yang dikonsumsi. Dari hasil pengukuran tersebut seluruh (100\%) responden mengalami penurunan kadar gula darah pada hari ke 14.

Tabel 3 Perbedaan hasil pemeriksaan kadar gula darah sewaktu penderita (responden) diabetes mellitus di Desa Sidoraharjo, Kecamatan Kedamean, Kabupatem Gresik sebelum pemberian bawang merah $100 \mathrm{mg} / \mathrm{kgBB}$ yang dijadikan serbuk selama 14 hari.

\begin{tabular}{llll}
\hline \multicolumn{2}{l}{$\begin{array}{l}\text { Kadar Gula Darah } \\
\text { Sewaktu }(\mathrm{mg} / \mathrm{dL})\end{array}$} & \multirow{2}{*}{$\begin{array}{l}\text { Selisih } \\
(\mathrm{mg} / \mathrm{dL})\end{array}$} & Keterangan \\
\cline { 1 - 1 } $\begin{array}{l}\text { Sebelu } \\
\mathrm{m}\end{array}$ & Sesudah & & \\
\cline { 1 - 2 } 278,93 & 251,64 & 27,29 & Lebih rendah \\
\hline
\end{tabular}

Signifikan $(\rho): 0,001$

Sumber: Data Primer April-Mei 2016

Pada tabel 5.12 menunjukkan bahwa dari 14 responden, seluruhnya mengalami penurunan kadar gula darah sewaktu setelah pemberian serbuk bawang merah 100 $\mathrm{mg} / \mathrm{kgBB}$ hal ini ditunjukkan dari hasil pengukuran kadar gula darah sewaktu sesudah perlakuan lebih rendah dari sebelum perlakuan. Hasil analisis menggunakan Wilcoxon Signed Ranks Test didapatkan nilai probabilitas $=0,001$. Olehkarena $\rho<\alpha(0,001<0,05)$ maka $\mathrm{H}_{0}$ ditolak dan $\mathrm{H}_{1}$ diterima yang berarti ada pengaruh pemberian bawang merah terhadap penurunan kadar gula darah pada penderita diabetes mellitus di Desa Sidoraharjo Kecamatan Kedamean, Kabupaten Gresik. Artinya kadar gula darah 14 responden sebelum dan sesudah pemberian serbuk bawang merah 100 $\mathrm{mg} / \mathrm{kgBB}$ berbeda (posttest lebih rendah dari pretest, yang berarti bahwa bawang merah berhasil menurunkan kadar gula darah secara signifikan.

\section{b. Pembahasan}

\section{Kadar Gula Darah Responden Sebelum Pemberian Bawang Merah}

Hasil penelitian pada tabel 5.10 dapat diketahui bahwa kadar gula darah responden sebelum mengonsumsi serbuk bawang merah $100 \mathrm{mg} / \mathrm{kgBB}$ seluruhnya (100\%) memiliki kadar gula darah dengan rata-rata sebesar 278,93 mg/dl yang bisa dipastikan 14 responden mengidap diabetes. Hal ini bisa disebabkan karena setengah $(50,0 \%)$ dari responden berusia 56-65 tahun (lansia akhir) yang terlihat pada tabel 5.1, hal tersebut sesuai dengan teori menurut Riyadi \& Sukarmin (2008) bahwa umumnya manusia mengalami penurunan fisiologi yang secara dramatis menurun dengan cepat pada usia setelah 40 tahun. Penurunan ini yang akan berisiko pada penurunan fungsi 
endokrin pankreas untuk memproduksi insulin.

Hasil penelitian menunjukkan bahwa dari 14 responden hampir seluruhnya $(78,6 \%)$ berjenis kelamin perempuan, ini terlihat pada tabel 5.2. Dari observasi masing-masing responden saat ditanya, ke 11 responden berjenis kelamin perempuan tersebut lebih sering mengalami stres dikarenakan mereka cenderung memikirkan masalah secara berlebihan. Menurut Riyadi \& Sukarmin, (2008) stres kronis cenderung membuat seseorang mencari makanan yang cepat saji yang kaya pengawet, lemak, dan gula. Makanan ini berpengaruh besar terhadap kerja pankreas. Stres juga akan meningkatkan kerja metabolisme dan meningkatkan kebutuhan akan sumber energi yang berakibat pada kenaikan kerja pankreas. Beban yang tinggi membuat pankreas mudah rusak hingga berdampak pada penurunan insulin.

Kenaikan kadar gula darah pada responden juga bisa disebabkan oleh adanya riwayat diabetes mellitus dalam keluarga yang terlihat pada tabel 5.4 yaitu dari 14 responden setengahnya $(50,0 \%)$ mempunyai riwayat diabetes mellitus dalam keluarganya. Hal tersebut sesuai dengan pernyataan Riyadi \& Sukarmin (2008) bahwa diabetes dapat menurun menurut silsilah keluarga yang mengidap diabetes. Ini terjadi karena DNA pada orang diabetes mellitus akan ikut diinformasikan pada gen berikutnya terkait dengan penurunan produksi insulin.

Selain karena riwayat keluarga, faktor yang dapat menyebabkan kenaikan kadar gula darah dan terjadinya diabetes mellitus adalah obesitas, berdasarkan tabel 5.5. Hampir setengahnya (42,9\%) dari 14 responden mengalami obesitas tingkat 1 . Kelebihan berat badan mengakibatkan selsel beta pankreas mengalami hipotropi yang akan berpengaruh terhadap penurunan produksi insulin. Hipertropi pankreas disebabkan karena peningkatkan beban metabolisme glukosa pada penderita obesitas untuk mencukupi energi sel yang terlalu banyak (Riyadi \& Sukarmin, 2008). Dapat disimpulkan bahwa berat badan sangat berpengaruh pada kondisi kesehatan, terutama terkait dengan masalah penyakit diabetes mellitus.

\section{Kadar Gula Darah Rersponden Setelah Pemberian Bawang Merah}

Hasil analisis dan interpretasi data yang dilakukan pada 14 responden yang memiliki kadar gula darah tinggi di Desa Sidoraharjo, Kecamatan Kedamean, Kabupaten Gresik, menunjukkan bahwa sesudah pemberian serbuk bawang merah $100 \mathrm{mg} / \mathrm{kgBB}$ kadar gula darah ke 14 responden memiliki ratarata sebesar 251,64 mg/dL.

Dari hasil pengukuran tersebut seluruh (100\%) responden mengalami penurunan kadar gula darah pada hari ke 14. Hal ini bisa disebabkan karena adanya zat dalam bawang merah yang dapat menurunkan kadar gula darah penderita yaitu flavonoid dan alilprophildisulfide. Menurut Jaelani (2007) bawang merah mengandung senyawa flavonoid dan alilprophildisulfide yang bersifat hipoglikemik, yaitu bisa menurunkan kadar gula darah. Senyawa kimia ini secara farmakologis juga dapat membantu kerja pankreas dalam memproduksi insulin. Dengan demikian, proses metabolisme glukosa menjadi glikogen dapat lebih lancar sehingga glukosa yang terlarut bersama darah akan berkurang.

Terlihat variasi penuruan kadar gula darah pada hari ke 2, hari ke 4, hari ke 6, hari ke 8 , hari ke 10 , hari ke 12 , dan hari ke 14, hal ini dapat dikarenakan perbedaan respon yang dihasilkan dari masing-masing responden terhadap serbuk bawang merah yang dikonsumsi, terutama pola makan responden. Tabel 5.8 menunjukkan bahwa sebagian besar $(64,3 \%)$ responden mengikuti pola makan sesuai diet diabetes mellitus yang diberikan dengan interval waktu tiga jam, meliputi tiga kali makanan utama dan tiga kali makanan selingan. Meskipun telah diberikan anjuran oleh peneliti tentang diet diabetes mellitus 5 
responden tidak dapat mengikuti pola makan selang tiga jam dikarenakan kesibukan dan susahnya menghilangkan kebiasaan makan pada jam-jam selain yang telah ditentukan serta sering mengonsumsi makanan tinggi lemak seperti gorengan. Mereka juga terbiasa untuk makan dengan porsi nasi yang lebih besar dengan alasan bisa cepat mengenyangkan dan meminimalkan lauk bahkan tanpa sayur sehingga dapat mengakibatkan penurunan kadar gula darah dari 5 responden tidak terlalu signifikan. Hal ini sesuai dengan teori yang dipaparkan oleh Riyadi \& Sukarmin (2008) pola makan yang tidak teratur dan cenderung terlambat juga akan berperan pada ketidakstabilan kerja pankreas.

\section{Analisis Pengaruh Bawang Merah Terhadap Penurunan Kadar Gula Darah Responden}

Hasil analisis dan interpretasi data yang dilakukan pada 14 responden yang mengalami hiperglikemi sebelum pemberian bawang merah pada penderita diabetes mellitus di Desa Sidoraharjo, Kecamatan Kedamean, Kabupaten Gresik, menunjukkan bahwa dari 14 responden memiliki kadar gula darah rata-rata sebesar $278,93 \mathrm{mg} / \mathrm{dL}$ (tinggi). Sedangkan sesudah diberikan serbuk bawang merah 100 $\mathrm{mg} / \mathrm{kgBB}$, dari 14 responden rata-rata kadar gula darah sewaktu yang dihasilkan mengalami penurunan yaitu sebesar 251,64 $\mathrm{mg} / \mathrm{dL}$ (turun). Selisih dari hasil pengukuran kadar gula darah responden sebelum dan sesudah diberikan bawang merah mempunyai rata-rata sebesar $27,29 \mathrm{mg} / \mathrm{dL}$. Dari hasil analisis lebih lanjut dengan menggunakan Wilcoxon Signed Ranks Test, didapatkan nilai probabilitas 0,001 . Karena $\rho<\alpha(0,001<0,05)$ maka $\mathrm{H}_{0}$ ditolak dan $\mathrm{H}_{1}$ diterima yang berarti ada pengaruh pemberian bawang merah terhadap penurunan kadar gula darah pada penderita diabetes mellitus di Desa Sidoraharjo Kecamatan Kedamean, Kabupaten Gresik.
Kadar gula darah adalah tingkat glukosa yang ada di dalam darah, konsentrasi gula darah diatur ketat dalam tubuh. Glukosa dialirkan melalui darah adalah sumber energi utama untuk sel-se tubuh (Kariadi, 2009). Kadar gula darah harus seimbang untuk kelangsungan metabolisme tubuh yang artinya tidak boleh terlalu tinggi dan terlalu rendah dari ammbang normal. Karena bisa menyebabkan ketidakseimbangan metabolisme tubuh sehingga mengganggu kesehatan yang pada akhirnya akan menimbulkan penyakit seperti diabetes mellitus, jika hal itu tak tertangani dengan baik makan akan muncul komplikasi. Menurut Novitasari (2012) komplikasi akibat diabetes mellitus dapat bersifat akut dan kronis. Komplikasi akut terjadi jika kadar glukosa darah seseorang meningkat atau menurun tajam dalam waktu relatif singkat. Kadar glukosa darah bisa menurun drastis jika penderita menjalani diet yang terlalu ketat. Perubahan yang besar dan mendadak dapat merugikan. Komplikasi kronis berupa kelainan pembuluh darah yang akhirnya bisa menyebabkan serangan jantung, ginjal, saraf, dan penyakit berat lainnya.

5 dari 14 responden mengalami penurunan kadar gula darah yang tidak terlalu signifikan bahkan selama pemberian serbuk bawang merah $100 \mathrm{mg} / \mathrm{kgBB}$ secara rutin setiap sore hari tiga jam setelah makan siang selama 14 hari mengalami penurunan kadar gula darah $7 \mathrm{mg} / \mathrm{dL}$ ini dikarenakan responden tersebut tidak menerapkan diet diabetes mellitus. Responden beranggapan bahwa hidupnya sudah tidak lama lagi jadi dia tidak ingin menyia-nyiakan hidup di dunia dengan makan makanan yang tidak menurut seleranya meskipun telah mengonsumsi serbuk bawang merah 100 $\mathrm{mg} / \mathrm{kgBB}$. Responden lebih sering makan makanan manis seperti martabak dan gorengan, bahkan makan tidak pada jamjam dan porsi tertentu. Untuk 4 responden yang masih mengalami penurunan di atas 10 $\mathrm{mg} / \mathrm{dL}$ ini juga karena penerapan diet yang 
tidak mereka ikuti dengan baik, mereka mengikuti pola pikir sebelum sakit bahwa nasi lebih diutama yaitu makan nasi dengan porsi besar tanpa menyeimbangkan lauk dan sayur.

Dari hasil penelitian yang dilakukan oleh Tri Purwaningsih FMIPA Farmasi UI tahun 1991, ternyata ekstrak umbi bawang merah dengan dosis $250 \mathrm{mg} / \mathrm{kg} \mathrm{BB}$, menyebabkan penurunan kadar gula darah normal sebesar 23,46\%. (Fadhli, 2013). Bawang merah (Allium cepa L. kelompok Aggregatum) adalah sejenis tanaman yang menjadi bumbu berbagai masakan Asia Tenggara dan dunia (Fadhli, 2013). Oleh karena itu bawang merah merupakan bahan herbal yang mudah didapat, murah, praktis, maka seluruh masyarakat akan memiliki/menyediakan bawang merah di rumahnya. Para peneliti India pernah melakukan riset terhadap bawang merah, baik berupa bawang merah yang telah dijus maupun bawang merah yang masih utuh. Rata-rata bobot umbi bawang merah yang diteliti sekitar 25-200 g pada subyek yang ditelitinya. Hasil riset tersebut menunjukkan bahwa semakin banyak bawang merah yang diberikan maka makin tinggi pula kadar gula darah yang berkurang. Tidak ada perbedaan khasiat antara bawang merah mentah dengan bawang merah yang sudah direbus (Utami, 2013). Khasiatnya dalam penurunan kadar gula darah dapat dijadikan alternatif/komplementer pengendali kadar gula darah pada pasien diabetes mellitus, bahkan bisa dikonsumsi secara langsung maupun dicampur dalam makanan seperti dijadikan bawang goreng.

\section{SIMPULAN}

\section{Simpulan}

1. Penderita diabetes mellitus memiliki rata-rata kadar gula darah seluruhnya tinggi (hiperglikemi) sebelum diberikan bawang merah di Desa Sidoraharjo, Kecamatan Kedamean, Kabupaten Gresik.

2. Penderita diabetes mellitus memiliki kadar gula darah sesudah diberikan bawang merah lebih rendah daripada sebelum diberikan bawang merah di Desa Sidoraharjo, Kecamatan Kedamean, Kabupaten Gresik.

3. Bawang merah mempengaruhi penurunan kadar gula darah pada penderita diabetes mellitus di Desa Sidoraharjo, Kecamatan Kedamean, Kabupaten Gresik.

\section{Saran}

\section{Bagi Institusi}

Instansi pendidikan merupakan pengembangan ilmu pendidikan dan ilmu pengetahuan, diharapkan lebih meningkatkan sumber bacaan yang terkait dengan penatalaksanaan diabetes mellitus terutama pengobatan non-farmakologis dalam hal ini herbal bawang merah sehingga dapat dijadikan alternative untuk mengendalikan kadar gula darah.

2. Bagi Penderita Diabetes Mellitus

Diharapkan penderita diabetes mellitus dapat menggunakan bawang merah sebagai pengendali kadar gula darah alternatif selain terapi dari dokter. Dan rutin memeriksakan kadar gula darah minimal setiap bulan sehingga terhindar dari komplikasi yang mungkin terjadi.

3. Bagi Masyarakat

Masyarakat dapat menjalankan pola hidup sehat dan rutin memeriksakan kadar gula darah minimal tiap bulan agar terhindar dari penyakit diabetes mellitus.

4. Bagi Peneliti Lain

a. Dapat mengembangkan penelitian ini dengan menggunakan metode penelitian yang menggunakan kelompok kontrol, sehingga dapat membandingkan antara penderita yang diberikan perlakuan dan tidak diberikan perlakuan.

b. Dapat mengembangkan penelitian ini dengan penyajian bawang merah yang berbeda, sehingga responden dapat lebih tertarik untuk menjadi sampel penelitian.

c. Dapat mengembangkan penelitian ini dengan waktu perlakuan lebih lama, dan dengan jumlah sampel yang lebih 
banyak, sehingga diharapkan mendapatkan hasil yang signifikan.

\section{DAFTAR PUSTAKA}

Fadhli, Aulia. (2013). Bumbu Dapur Nusantara Super Lengkap: Rahasia Kegunaan dan Khasiat Bumbu Dapur Nusantara. Yogyakarta: Familia.

Jaelani. (2007). Khasiat Bawang Merah. Yogyakarta: Kanisius.

Kariadi, Sri Hartini KS. 2009. Diabetes? Siapa Takut!!. Bandung: Qanita.
Novitasari, Retno. (2012). Diabetes Mellitus Dilengkapi Senam DM. Yogyakarta: Nuha Medika.

Riyadi, Sujono \& Sukarmin. (2008). Asuhan Keperawatan pada Pasien dengan Gangguan Eksokrin dan Endokrin pada Pankreas. Yogyakarta: Graha Ilmu.

Utami, Prapti. (2013). Umbi Ajaib Tumpas Penyakit. Jakarta: Penebar Swadaya.

Departemen Kesehatan Republik Indonesia. (2009). Sistem Kesehatan Nasional. Jakarta: Depkes RI 